\title{
Framfaraskref: Ný réttargeðdeild
}

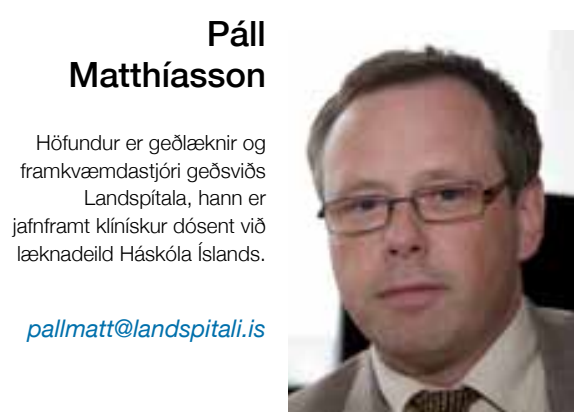

Pann 29. febrúar síðastliðinn opnaði velferðarráðherra nýja réttargeðdeild Landspítalans á Kleppi. Rétt er að staldra við og skoða hvers vegna petta er mikilvægt framfara- og umbótaskref.

\section{Sagan}

Er kom fram á 9. áratug síðustu aldar urðu kröfur um réttargeðdeild á Íslandi háværar. Slík deild opnaði að lokum árið 1992 en ekki á Kleppi, eins og nærtækt hefði verið, heldur nauðlenti deildin í óhentugu húsnæði að Sogni í Ölfusi.

Starfsemin hefur oft sætt gagnrýni síðan. Árið 1999 gerði „CPT-nefndin“ töluverðar athugasemdir við aðbúnað að Sogni. Spurt var hvort ekki væri rétt að „flytja stofnunina á stað sem ekki væri eins fjarri höfuðstaðnum og par sem sjúklingar kynnu að njóta góðs af auðveldari aðgangi að faglegri pekkingu og aðstöðu til [...] umönnunar." ${ }^{\prime 12}$

Árið 2008 tók geðsvið Landspítala út starfsemi Sogns að ósk heilbrigðisráðuneytisins. Tilefnið var áhyggjur af faglegu starfi, miklir erfiðleikar við faglega mönnun og rekstrarerfiðleikar. Sjúklingar deildarinnar höfðu kvartað til landlæknis, umboðsmanns Alpingis og Geðhjálpar yfir umönnun og aðstæðum að Sogni. Niðurstaða úttektarinnar var sú að Landspítali tók við rekstri Sogns af Heilbrigðisstofnun Suðurlands 1. apríl 2009 og er Sigurður Páll Pálsson yfirlæknir frá peim tíma. Árið 2008 var rekstrarhalli Sogns tugir milljóna en deildin hefur verið rekin á pari frá 2009.

Pverfaglegur hópur fagfólks gjörbreytti umönnun sjúklinga. Húsnæðið var samt áfram tæplega $600 \mathrm{~m}^{2}$ á premur hæðum, pröngt og hentaði illa til að skapa öruggan ramma utan um starf réttargeðdeildar. Staðsetningin torveldaði endurhæfingu sjúklinga og smæðin stefndi í hættu öryggi starfsmanna og sjúklinga. Í janúar 2011 var í ljósi pessa í minnisblaði frá Landspítala til velferðarráðherra hvatt til pess að hefja pegar flutning réttargeðdeildar frá Sogni að Kleppi. Landlæknir studdi pau sjónarmið.

Framkvæmdastjórn Landspítala ákvað í októberbyrjun 2011 að loka Sogni og opna nýja réttargeðdeild á Kleppi. Velferðarráðherra sampykkti pá ákvörðun og 12. október síðastliðinn tilkynnti leiðarahöfundur starfsfólki Sogns og síðan öðrum hagsmunaaðilum ákvörðunina. Vinna við nýja réttargeðdeild á Kleppi hófst pegar, en kostnaður við pær breytingar var sem betur fer hóflegur, par sem hægt var að nýta tvær ónotaðar deildir á 2. hæð aðalbyggingar Klepps.

\section{Árangur Sogns}

Sogn gegndi mikilvægu hlutverki í geðheilbrigðiskerfi landsins í tvo áratugi og starfsfólk deildarinnar á pakkir skildar fyrir óeigingjarnt starf. Árangur deildarinnar var hins vegar ekki „100\%“ eins og haldið hefur verið fram, enda óraunhæft að búast við slíku. Af 44 útskrifuðum sjúklingum eru $18 \%$ látnir, nær allir fyrir fimmtugt. Árangur var ekki góður hjá 7, par sem voveiflegir atburðir áttu sér stað hjá premur og fjórir brutu af sér aftur.

\section{Ný réttargeðdeild}

Á Kleppi er aðbúnaður sjúklinga réttargeðdeildarinnar til fyrirmyndar. Húsnæðið er nærri $1000 \mathrm{~m}^{2}$, rammbyggt á einni hæð, með sérinngangi gegnum bjartan garð, umlukinn hárri tvöfaldri girðingu. Betra aðgengi er að fagfólki og háskólasamstarfi, styttra er fyrir fjölskyldur sjúklinga að koma í heimsókn og útskriftarferli fer fram á höfuðborgarsvæðinu pangað sem flestir útskrifast.

Öryggi sjúklinga og starfsmanna er miklu betra. Deildin er stærri og auðveldara að aðskilja sjúklinga. Mjög gott öryggisherbergi er til staðar, öflugt öryggiskerfi, nær öll deildin er í sjónlínu við vaktherbergi, stutt er í prjár aðrar legudeildir og par með annað starfsfólk ef pörf krefur. Geta til að sinna lögboðnu hlutverki batnar, par sem deildin stækkar úr 7 í 9 rúm, auk möguleika á frekari stækkun. Nándin við aðrar deildir skapar einnig aðhald og möguleika á að fylgjast náið með gæðum pjónustunnar. Í viðbót við ofannefnd fagleg rök er reksturinn nærri fimmtungi ódýrari.

\section{Lokaord}

Rök finnast á móti lokun Sogns. Pyngst vega par byggðasjónarmið. Ótti við breytingar og ótti við að fordómar gegn geðsjúkum magnist eru önnur rök sem hafa heyrst gegn nýrri réttargeðdeild og pá frekar úr hópi eldra fagfólks.

Rök með nýrri réttargeðdeild eru pó miklu sterkari. Á heilbrigðisstofnun verða hagsmunir sjúklinga að ganga fyrir. Með nýrri réttargeðdeild á Kleppi er verið að setja í fyrsta sæti hagsmuni pessa viðkvæma sjúklingahóps (með betri og mannúðlegri meðferð og aðstæðum) og hagsmuni pjóðfélagsins í heild (með fleiri plássum, bættu öryggi og minni rekstrarkostnaði). Jafnframt fékk starfsfólk Sogns nýja vinnu á réttargeðdeildinni á Kleppi ef pað óskaði pess.

Рað er sjaldgæft að hægt sé að slá svo margar flugur í einu höggi og bæta svo eindregið pjónustu á sama tíma og rekstrarhagræðing næst fram. Рað er oft sagt að menningarstig pjóða sjáist á pví hvernig pær koma fram við sína minnstu bræður. Меð pví að stíga petta framfaraskref í meðferð alvarlega geðsjúks fólks sem hefur orðið fyrir pví óláni að fremja glæpi, getum við sem pjóð borið höfuðið hærra.

\section{Heimildir}

1. Skýrsla Evrópunefndarinnar um varnir gegn pyntingum og ómannúðlegri og niðurlægjandi meðferð og refsingum til ríkisstjórnar Îslands. Febrúar 1999.

2. Bráðabirgðaskýrsla ríkisstjórnar Íslands til Evrópunefndar um varnir gegn pyndingum og ómannlegri eða vanvirðandi meðferð eða refsingu (CPT). 01.10.1999. innanrikisraduneyti.is/utgefid-efni/til_nefnda/nr/663 - mars 2012.

A drive for quality: a new forensic unit in Iceland Dr. Pall Matthiasson MD, MRCPsych, PhD Chief Executive of Mental Health Services, Consultant Psychiatrist, National University Hospital of Iceland, Clinical Associate Professor, University of Iceland, WHO Counterpart for Mental Health. 